\title{
Thyroid gland development in Rachycentron canadum during early life stages
}

\author{
ADRIANA P.S. OTERO ${ }^{1,2}$, RICARDO V. RODRIGUES ${ }^{1,2}$, \\ LUÍS A. SAMPAIO ${ }^{1,2}$, LUIS A. ROMANO ${ }^{1,3}$ and MARCELO B. TESSER ${ }^{1,2}$ \\ ${ }^{1}$ Programa de Pós-Graduação em Aquicultura, Universidade Federal do Rio Grande/FURG, \\ Av. Itália, Km 8, Caixa Postal 474, 96200-970 Rio Grande, RS Brasil \\ ${ }^{2}$ Instituto de Oceanografia/IO, Laboratório de Piscicultura Estuarina e Marinha, \\ Universidade Federal do Rio Grande/FURG, 96203-900 Rio Grande, RS, Brasil \\ ${ }^{3}$ Instituto de Oceanografia/IO, Laboratório de Patologia e Imunologia de Organismos Aquáticos, \\ Universidade Federal do Rio Grande/FURG, 96210-030 Rio Grande, RS, Brasil
}

Manuscript received on May 8, 2013; accepted for publication on October 28, 2013

\begin{abstract}
The aim of this study was to describe the ontogeny of thyroid follicles in cobia Rachycentron canadum. Larvae were sampled daily $(\mathrm{n}=15$ - 20) from hatching until 15 dah (days after hatching). Following, larvae were sampled every two days by 28 dah; a new sample was taken at 53 dah. The samples were dehydrated, embedded in Paraplast, and sections of $3 \mu \mathrm{m}$ were dewaxed, rehydrated and stained with HE and PAS. A single follicle was already present 1 dah and three follicles were found 8 dah. The number of follicles increased up to 19 on 53 dah. The diameter of follicles and follicular cell height were lower 1 dah (6.83 \pm 1.00 and $4.6 \pm 0.01 \mu \mathrm{m})$, but increased from 8 dah $(24.03 \pm 0.46 \mu \mathrm{m}$ e $6.43 \pm 0.46 \mu \mathrm{m})$. From 8 dah, the presence of reabsorption vesicles was observed in the colloid and from the 19 dah some follicles did not present colloid. The early thyroid follicle appearance in cobia larvae as well as the high quantity of follicles without colloid and/or with vesicles even after the metamorphosis, might be the explanation of the fast growth of the cobia.
\end{abstract}

Key words: colloid, follicles, larvae, metamorphosis, thyroid tissue.

\section{INTRODUCTION}

The cobia Rachycentron canadum (Linnaeus 1766) is a marine, pelagic species, with migratory habits and wide distribution in tropical and subtropical waters of the Atlantic, Pacific and Indian Oceans (Shaffer and Nakamura 1989). Cobia is considered a promising candidate for aquaculture due to its high growth rates, reaching 4 to $6 \mathrm{Kg}$ within a year in captivity (Benetti et al. 2008, Sampaio

Correspondence to: Marcelo Borges Tesser

E-mail: mbtesser@gmail.com et al. 2011). In this way, several researches were conducted in order to improve the rearing techniques such as: nutritional requirements (Fraser and Davies 2009), reproduction and larval rearing (Liao et al. 2004, Faulk and Holt 2005), effects of nitrogenous compounds and salinity (Resley et al. 2006, Rodrigues et al. 2007, 2011) and the use of immunostimulants and vaccines (Leaño et al. 2003, Lin et al. 2006).

The thyroid tissue in fish, through their iodine products, thyroxine (T4) and triiodothyronine (T3), 
exert direct influence on fish metabolism, growth, and metamorphosis (Brown and Bern 1989). A marking example of thyroid hormones' (THs) influence is observed during flatfish metamorphosis, where symmetrical pelagic larvae transform into a benthonic asymmetrical juvenile. The eye migration and the development of the digestive tract are morphological alterations under TH control (Inui and Miwa 1985, Piñuela et al. 2004). Other than that, the THs also have primordial role on survival, growth, and development of fish larvae that do not have such a marked metamorphosis (Lam 1980, Urbinati et al. 2008).

The synthesis of TH takes place in the thyroid follicles, under control of the thyroid-stimulating hormone (TSH) released by the pituitary (Baker 1964, Eales and Brown 1993, Yamano 2005). These follicles are the functional unit of the thyroid gland and are composed by a unique layer of follicular cells, which in turn, produce a colloidal lumen rich in thyroglobulin (Tg). The follicular cells absorb the Tg in order to produce THs (Takashima and Hibiya 1995).

A relationship between thyroid follicle morphology and its activity has been postulated by Tanaka et al. (1995). Evidence of high follicle activity for Paralichthys olivaceus and Solea senegalensis include an increasing number and size of the follicles, the change of cell shape from ovoid to cubic or cylindrical, and the presence of reabsorption vesicles in the colloid. These characteristics of high cell activity were observed during the metamorphosis period, coinciding with increasing levels of plasmatic THs (Delgado et al. 2006, Einarsdóttir et al. 2006).

In light of the above, the knowledge of ontological alterations of the thyroid may enable a better understanding on the role of this tissue for larval cobia development. Studies dealing with organs and tissue development during the early life history of cobia are scarce, and mainly focus on the digestive tract development (Faulk et al.
2007, Salze et al. 2011). The aim of this study is to describe the thyroid follicle development in cobia larvae and juvenile.

\section{MATERIALS AND METHODS}

\section{LARVAL REARING}

Cobia larvae were produced at Aqualider Ltda., Pernambuco, Brazil, according to the protocol proposed by Benetti et al. (2008) with modifications. Newly hatched larvae were stocked in a fiberglass tank $(12,000 \mathrm{~L})$ at the density of 15 larvae $\mathrm{L}^{-1}$. The tanks were kept in a flow through system with a water exchange rate of $500 \%$ per day. Water temperature was kept at $29.5 \pm 0.3^{\circ} \mathrm{C}$ and salinity at 35 . Oxygen concentration and $\mathrm{pH}$ were $6.5 \mathrm{mg}$ $\mathrm{O}_{2} \mathrm{~L}^{-1}$ and $8.09 \pm 01$, respectively.

Larvae were first fed 2 dah exclusively on rotifers (Brachionus plicatilis). Prey density was kept at 5 rotifers $\mathrm{mL}^{-1}$ until 6 dah. Beginning 7 dah, enriched rotifers were offered to the larvae along with Artemia nauplii (prey density of 0.1 and 1.0 nauplii $\mathrm{mL}^{-1}$ ). While larvae were fed on rotifers, the green water technique was used adding the microalgae Nannochloropsis oculatta at the density of $15 \times 10^{4}$ cells $\mathrm{mL}^{-1}$. The use of rotifers was discontinued 9 dah, thereafter larvae were fed exclusively on Artemia nauplii for two days. Enriched Artemia were first offered 11 dah and larvae were co-fed on a commercial diet (NRD, Inve, USA - 59\% protein, 16\% lipids) from 16 dah onwards until weaning was completed 28 dah.

SAMPLING AND HISTOLOGICAL ANALYSIS

Cobia larvae ( $\mathrm{n}=15$ to 20 ) were sampled, euthanized in anesthetic (Aqui - S, Lower Hut, New Zealand) at $30 \mathrm{ppm}$, and immediately fixed in $20 \% \mathrm{v} / \mathrm{v}$ buffered formaldehyde ( $\mathrm{pH}$ 7.2). Samples were taken daily from recently hatched larvae (0 dah) until 15 dah, and after that period every two days until 28 dah. A juvenile sample was taken 53 dah. 
Prior to the histological processing, the fixed larvae had their total length measured under a stereoscopic microscope (Wild M5A-HeerbruggSwitzerland) with a micrometric ocular. Fish larger than $12 \mathrm{~mm}$ were measured with a digital caliper. Larvae were dehydrated in a graded series of ethanol and xylol in an automatic tissue processing (LUPE PT 05 - Lupetec - São Carlos - São Paulo - Brazil), embedded in Paraplast ${ }^{\circledR}$ (McCormick Scientific - St. Louis - Missouri - USA) and sectioned $3 \mu \mathrm{m}$ in a microtome (LUPE MRP 03 - Lupetec - São Carlos - São Paulo - Brazil). The sections were stained with hematoxylin and eosin or with PAS and examined for the presence of thyroid follicles using a light microscope (OlympusBX 45 - Olympus America Inc. - Center Valley - Pennsylvania - E.U.A.) coupled to a digital camera (Olympus DP 72 - Olympus America Inc. - Center Valley - Pennsylvania - USA) to capture images. The number of cells in the follicles, and their diameter and height were measured through an integration ocular with $0.01 \mu \mathrm{m}$ intervals in a 400x augmentation according to Weibel (1980).

\section{RESULTS}

\section{THYROID FOLLICLES DEVELOPMENT}

The histological analysis revealed that the thyroid follicles were individually dispersed under the pharynx, adjacent to the ventral aorta and near the insertion of the branchial arcs (Fig. 1). The first evidence of thyroid follicle formation in cobia larvae was observed on the 1 dah ( 24 hours after eclosion). This structure was composed by a unique thyroid follicle formed by a layer of plane epithelial cells, which surrounded a colloidal lumen (Fig. 2). The number of follicles increased progressively with larvae age, indicating three follicles at the 8 dah, six follicles 10 dah, seven follicles 14 dah, 11 follicles 19 dah, 18 follicles were counted at the 23 dah and 19 were observed at 53 dah (Table I).

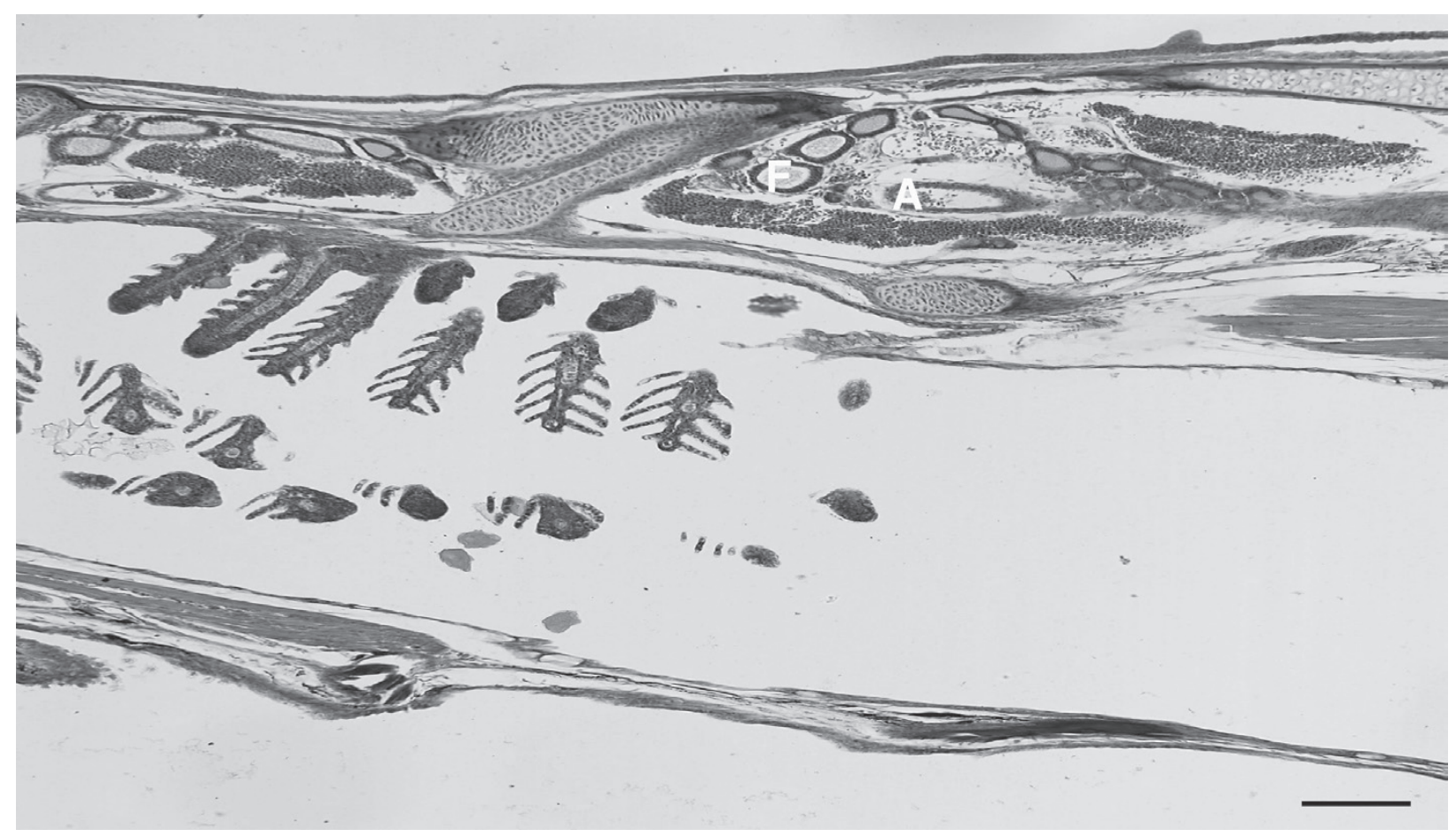

Figure 1 - Thyroid follicles in $R$. canadum larvae at $23^{\text {rd }}$ dah $(\mathrm{F}$ - follicle, A- aorta). (Bar $=200 \mu \mathrm{m})$. Section was stained with Haematoxylin-Eosin. 


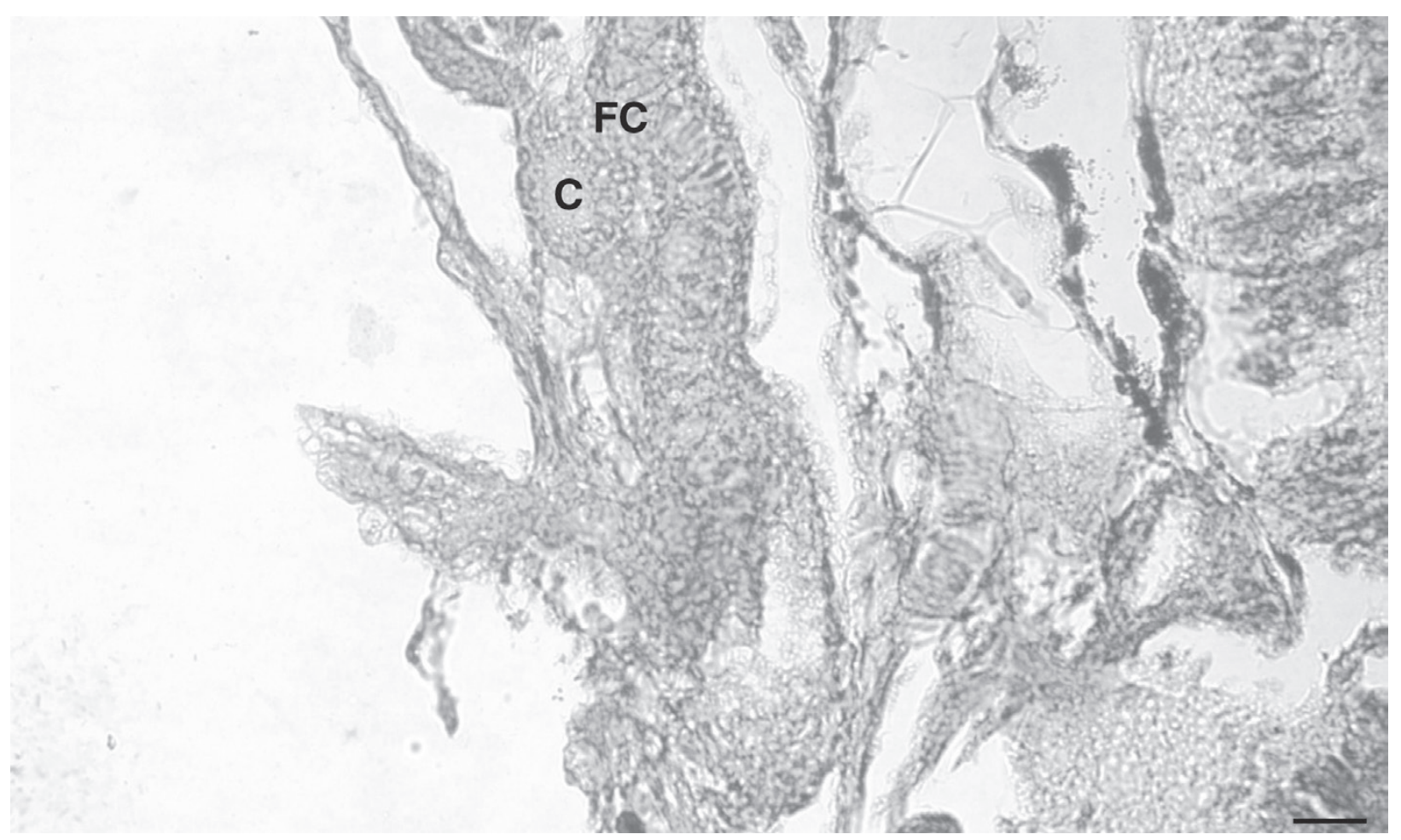

Figure 2 - Thyroid follicle $R$. canadum larvae at the $1^{\text {st }}$ dah (FC - follicular cells FC, C colloid C). (Bar $\left.=20 \mu \mathrm{M}\right)$. Section was stained with Haematoxylin-Eosin.

TABLE I

Diameter $(\mu \mathrm{m})$, epithelial cell heights $(\mu \mathrm{m})$ of follicular cell and number of follicles in Rachycentron candum larvae and juveniles.

\begin{tabular}{ccccc}
\hline DAH & Diameter $(\mu \mathrm{m})$ & Epithelial cell height $(\mu \mathrm{m})$ & $\begin{array}{c}\text { Number of follicles } \\
\text { per larvae }(\mu \mathrm{m})\end{array}$ & Mean larvae total length $(\mathrm{mm})$ \\
\hline 1 & $6.83 \pm 1.0$ & $4.60 \pm 0.01$ & 1 & $3.8 \pm 0.04$ \\
$2^{*}$ & 15.00 & 4.00 & 1 & $4.1 \pm 0.05$ \\
$4^{*}$ & 15.80 & 4.00 & 1 & $4.4 \pm 0.05$ \\
$5^{*}$ & 21.60 & 4.50 & 1 & $4.8 \pm 0.20$ \\
8 & $24.03 \pm 4.19$ & $6.43 \pm 0.46$ & 3 & $6.5 \pm 1.7$ \\
10 & $27.90 \pm 0.30$ & $7.90 \pm 0.40$ & 6 & $7.6 \pm 0.1$ \\
14 & $30.87 \pm 0.76$ & $9.03 \pm 0.59$ & 7 & $16.1 \pm 0.6$ \\
19 & $36.53 \pm 1.01$ & $10.00 \pm 0.17$ & 11 & $24.0 \pm 1.0$ \\
21 & $44.90 \pm 0.66$ & $10.23 \pm 0.30$ & 15 & $29.8 \pm 2.17$ \\
23 & $47.13 \pm 0.30$ & $9.87 \pm 0.29$ & 18 & $34.7 \pm 1.19$ \\
28 & $77.90 \pm 0.46$ & $9.73 \pm 0.06$ & 18 & $45.2 \pm 2.31$ \\
53 & $80.57 \pm 0.97$ & $9.80 \pm 0.10$ & 19 & $154.0 \pm 4.6$ \\
\hline
\end{tabular}

${ }^{*}$ Follicle was found in only one larvae. At least 3 larvae per sampling day had their follicle measured.

On the $8^{\text {th }}$ dah an epithelial cell differentiation into cuboid was observed with the presence of small reabsorption vesicles in the colloid (Fig. 3), which were more evident 19 dah. No colloid was observed in some follicles 19 dah. In the $23^{\text {rd }}$ dah, the colloids presented high concentration of reabsorption vesicles (Fig. 4).

The follicle diameter and follicular cell height increased concomitant with larval growth. The diameter of the thyroid follicle at the $1^{\text {st }}$ dah 


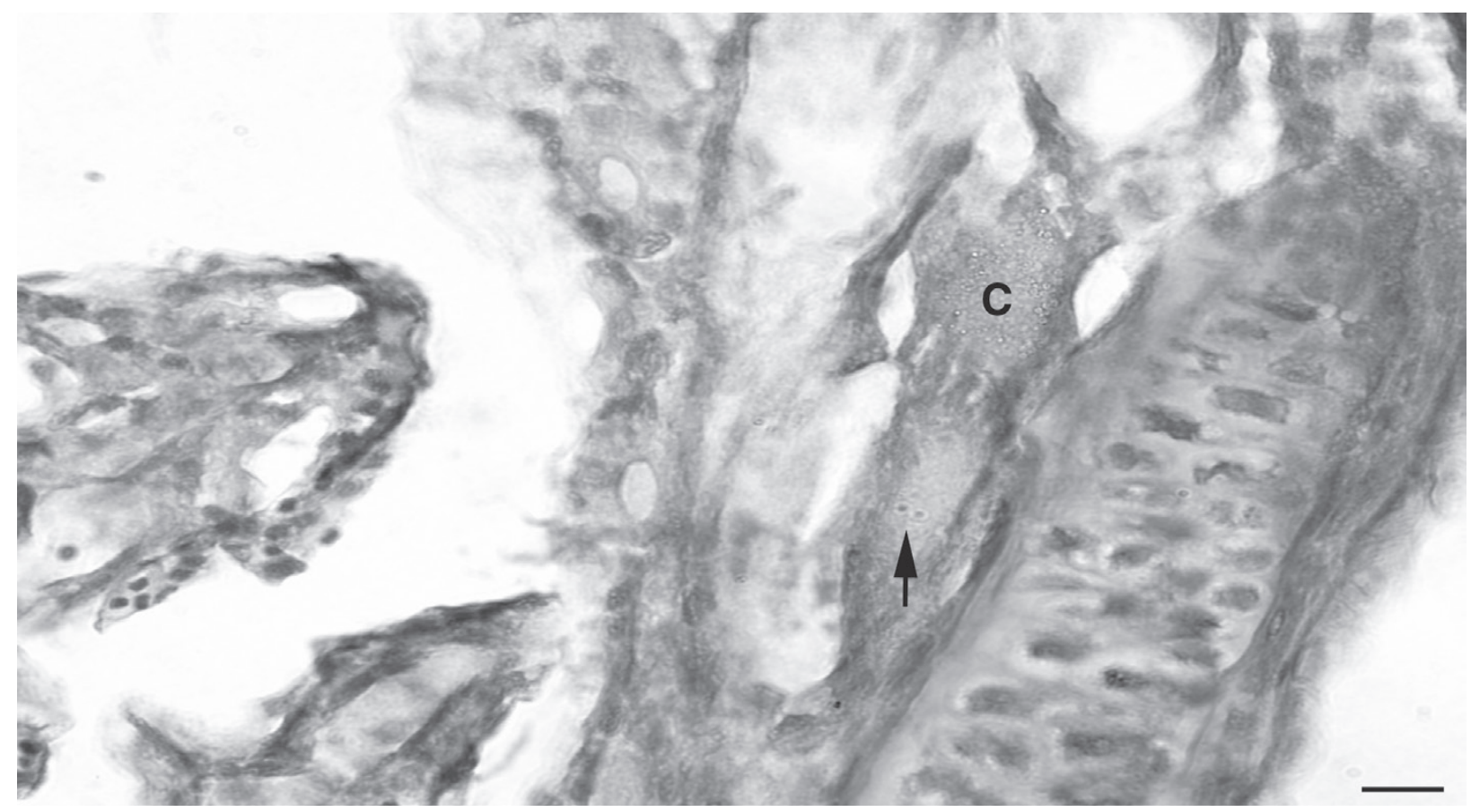

Figure 3 - Thyroid follicles in the $R$. canadum larvae with $8^{\text {th }}$ dah $(\mathrm{C}-$ collid, Arrow - reabsorption vesicles $) .($ Bar $=20 \mu \mathrm{m})$. Section was stained with Haematoxylin-Eosin.

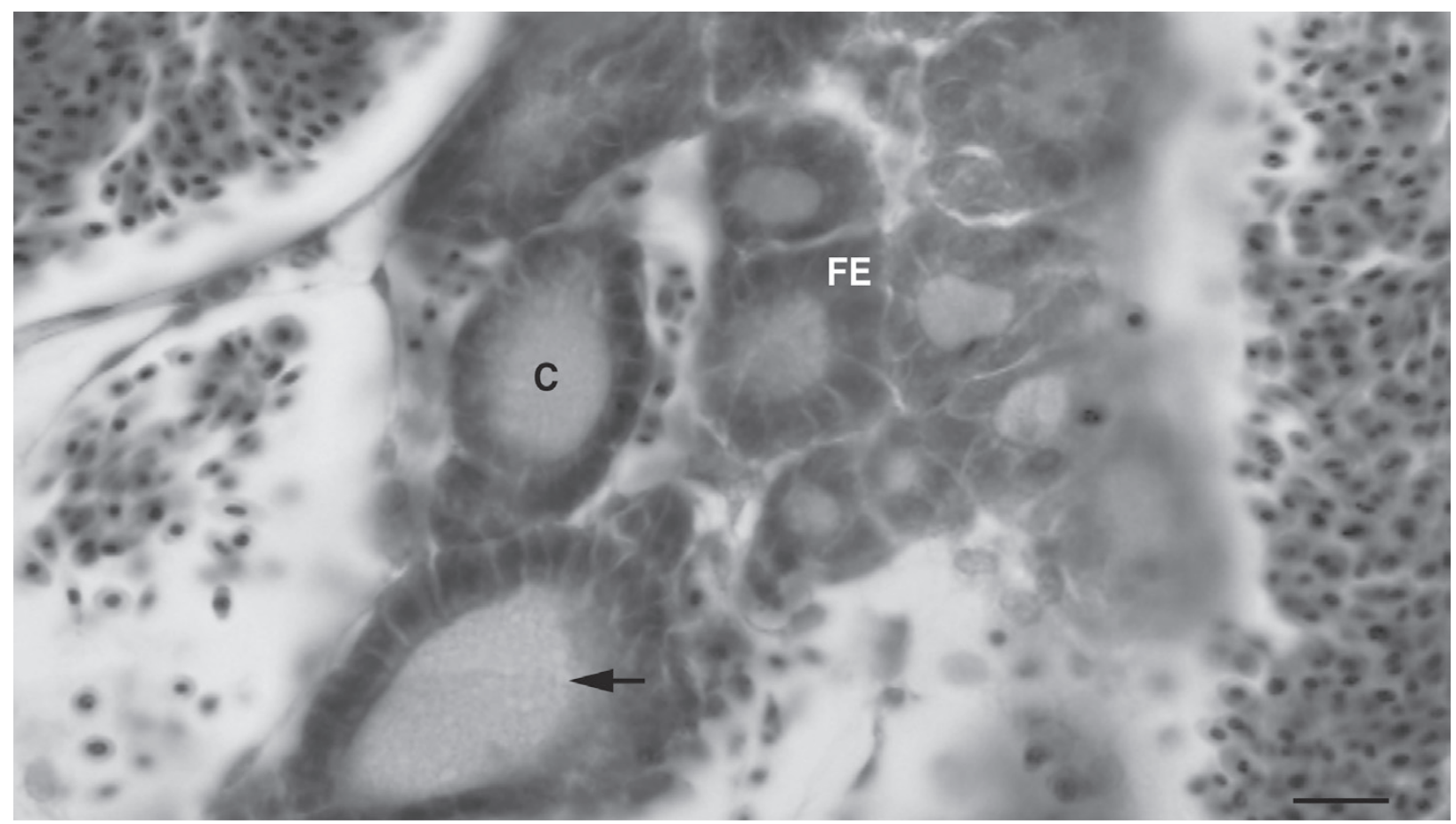

Figure 4 - Thyroid follicles in $R$. canadum juveniles at $23^{\text {rd }}$ dah $(\mathrm{C}$ - colloid, FE - follicle epithelium, arrow - reabsorption vesicle. (Bar $=20 \mu \mathrm{m})$. Section was stained with Haematoxylin-Eosin. 
measured $6.83 \pm 1.0 \mu \mathrm{m}$, and 8 dah they reached $24.0 \pm 0.4 \mu \mathrm{m}$. For older cobia (53 dah), the diameter of the follicles reached $80.57 \pm 0.9 \mu \mathrm{m}$ (Table I). The follicular epithelial cell height at the $1^{\text {st }}$ dah was $4.6 \pm 0.01 \mu \mathrm{m}, 6.43 \pm 0.46 \mu \mathrm{m}$ at 8 dah and reached $10.23 \pm 0.3 \mu \mathrm{m}$ at 21 dah, with no further increment (Table I).

Fish sampled at the $53^{\text {rd }}$ dah presented follicles with the same morphological characteristics observed in the $23^{\text {rd }}$ larvae follicles, which were the presence of numerous vesicles and some follicles without colloid (Fig. 5).

\section{DISCUSSION}

The thyroid gland in birds, reptiles and mammals is an organ anatomically recognized. In mammals and in human beings, the thyroid is located in the anterior region of the neck with two lobules well

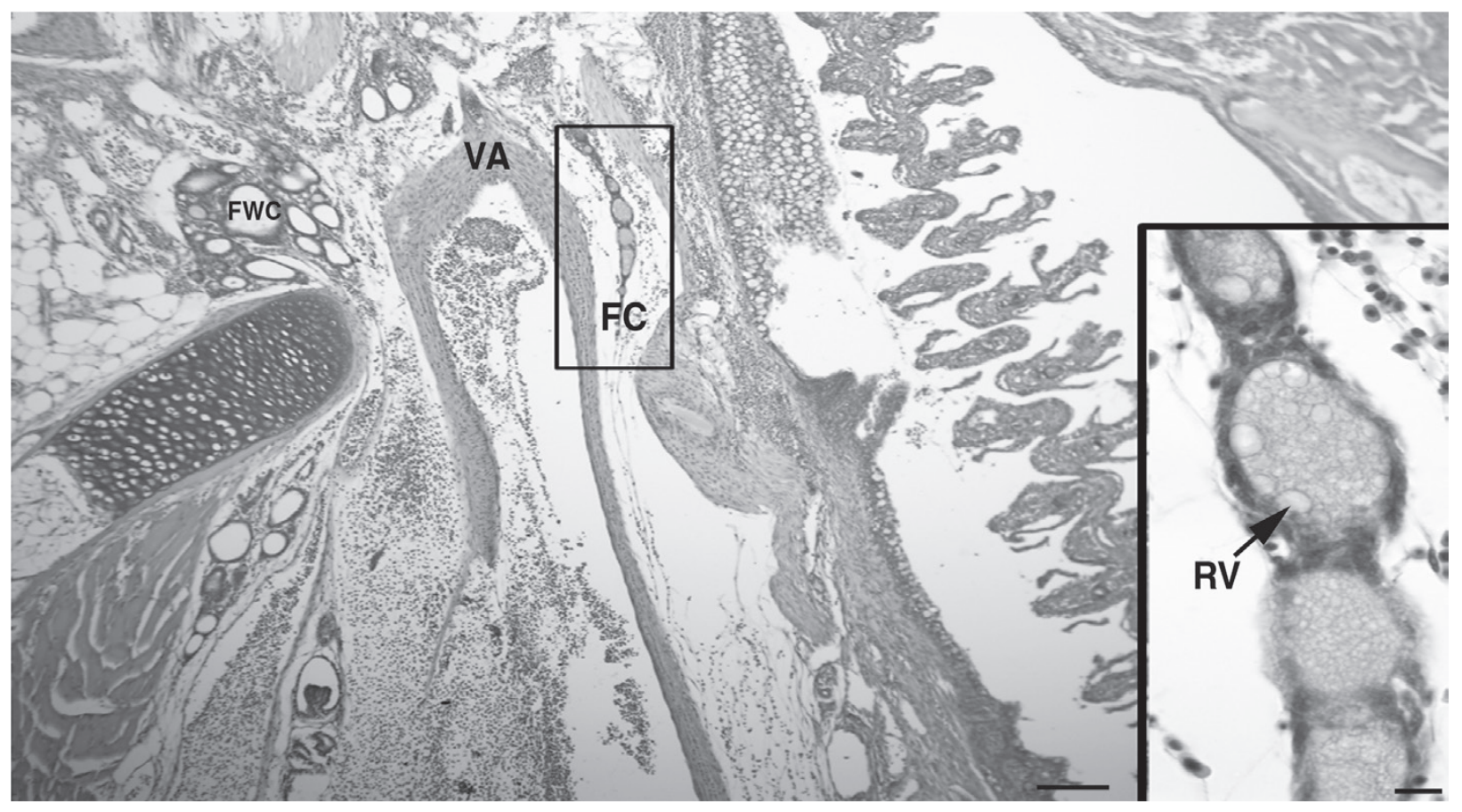

Figure 5 - Development of thyroid tissue in the R.canadum juveniles at $53^{\text {rd }}$ dah (FC - follicle with colloid, FWC - Follicle without colloid, VA - Ventral aorta) $(\mathrm{Bar}=200 \mu \mathrm{m})$. Insert: Augmentation of the rectangle $(\mathrm{RV}-$ reabsorption vesicle $)($ Bar $=20 \mu \mathrm{m})$. Section was stained with Haematoxylin-Eosin.

defined and an isthmus that connect them, bordered by a fine connective tissue capsule (Decuypere et al. 2005, Salgado et al. 2011). In fish, the thyroid is not macroscopically recognized but present scattered thyroid follicles (Gorbman et al. 1983). Anatomically the thyroid tissue in teleost fishes is composed by several follicles, which can be found near the ventral aorta and to the arterial bulb (Santamaría et al. 2004, Delgado et al. 2006) and in the insertion of the branchial arch (Einarsdóttir et al. 2006), as was also observed for cobia in the present study.
The first thyroid follicle is observed during the larval development of marine fish. However, the moment of appearance varies among species. According to Tanaka et al. (1995) fish can be categorized, according to the moment of thyroid follicle appearance, into an early appearance group in which thyroid follicles are differentiated at hatching and a late-appearance group in which differentiation of the thyroid occurs at the time of complete yolk reabsorption. The former group is mainly composed of species with demersal eggs 
and/or ovoviviparous species, and the latter of species with pelagic eggs. In Dentex dentex, the first follicle was detected before mouth opening (3 dah) (Santamaría et al. 2004). In Sciaenops ocellatus it occurs before the complete yolk consumption (3 dah) (Domínguez and Holt 2006), for Sparus aurata at $4 \mathrm{dph}$ (Power 2001) and for $S$. senegalensis the first follicles were also observed on the first feeding (4 dah) (Delgado et al. 2006). For cobia, the first follicle was observed before the first feeding on the $1^{\text {st }}$ dah, being, as far as we know, the only studied pelagic species with an early thyroid follicle development. The thyroid follicle appearance during the transition of the endogenous feeding to the exogenous is essential for the synthesis of its own THs, because during the embryonary development and during the yolk sac absorption the THs are from maternal origin (Tagawa and Hirano 1987, 1990, Tanaka et al. 1995, Yamano 2005, Delgado et al. 2006).

It was observed by Einarsdóttir et al. (2006) in Hippoglossus hippoglossus that with larval development, the number of thyroid follicles increase and the colloid volume decreases. The authors attributed this phenomenon as indicative of the thyroid tissue activity. In human beings the colloid secretion and reabsorption are also indicative of thyroid activity (Sommers 1977). Besides that, larvae of $S$. senegalensis show vacuoles in the colloid periphery, suggesting that the thyroid is functional and apt to secrete THs (Delgado et al. 2006). In this work, cobia larvae with 8 dah presented vacuoles in the colloid suggesting its activity. However, the follicles displayed activity from 19 dah onwards, since during this period, a higher number of follicles, and a larger concentration of vesicles in the periphery with smaller colloid volume were noted.

The increase in the follicular cell height and the follicle size are also characteristics that can be used to correlate the thyroid activity and the metamorphosis process. Klaren et al. (2008) observed an increase in the follicular cell height for pre-metamorphic $S$. senegalensis $\left(12^{\text {th }}\right.$ dah), whereas, Delgado et al. (2006) studying the same species evidenced the increase in the follicles size at the beginning of metamorphosis. On the other hand, the same authors reported that the follicle number and the follicular cell height in S. senegalensis remained constant and decreased, respectively after metamorphosis was completed. In this study, thyroid follicles of cobia larvae showed the same pattern described for $S$. senegalensis.

Considering the influence of the thyroid tissue on fish growth and metabolism, it can be suggested that the early appearance of thyroid follicles in cobia larvae, as well as the high quantity of follicles without colloid and/or with vesicles even after the metamorphosis, such as found for cobia juveniles at the $53^{\text {rd }}$ dah, might be the explanation for the fast growth of cobia.

\section{ACKNOWLEDGMENTS}

The authors are grateful to The Ministry of Fisheries and Aquaculture (MPA). This research was supported by Conselho Nacional de Desenvolvimento Científico e Tecnológico (CNPq) (\#483433/2007-1 and Edital MCT/CNPq/CT-Agronegócio/MPA36/ 2009 \# 559741/2009-0). Adriana Patricia Salgado Otero is a graduate student of the Aquaculture Program at FURG and is supported by Coordenação de Aperfeiçoamento de Pessoal de Nível Superior (CAPES). Luís A. Sampaio and Luis A. Romano are research fellows of CNPq.

\section{RESUMO}

O objetivo deste estudo foi descrever a ontogenia dos folículos da tireóide em Rachycentron canadum. Larvas foram coletadas diariamente $(n=15-20)$ desde a eclosão até 15 dae (dias após eclosão). Posteriormente foram coletadas a cada dois dias até o 28 dae; uma nova amostragem ocorreu aos 53 dae. As larvas foram desidratadas e emblocadas em Paraplast e secções de $3 \mu \mathrm{m}$ foram desparafinadas, reidratas e coradas com $\mathrm{HE}$ e 
PAS. Um folículo estava presente ao 1 dae e três foram encontrados aos 8 dae. O número de folículos aumentou até 19 aos 53 dae. O diâmetro dos folículos e a altura das células foliculares foram menores ao 1 dae $(68,3 \pm 1,00 \mathrm{e}$ $4,6 \pm 0,01 \mu \mathrm{m})$, mas aumentou a partir do 8 dae $(24,03 \pm$ $0,46 \mu \mathrm{m}$ e $6,43 \pm 0,46 \mu \mathrm{m})$. A partir do 8 dae a presença de vesículas de reabsorção foi observada no colóide e a partir de 19 dae alguns folículos não apresentaram colóide. O surgimento precoce do folículo da tireóide no bijupirá assim como a grande quantidade de folículos sem colóide e/ou com a presença de vesículas mesmo após a metamorfose podem ser a explicação do rápido crescimento da espécie.

Palavras-chave: colóide, folículos, larvas, metamorfose, tecido tireoideano.

\section{REFERENCES}

BAKER BI. 1964. Pituitary-Thyroid Relationship during development in the teleost Herichthys cyanoguttatus: A histophysiologic study. Gen Comp Endocrinol 4: 164-175.

BENETTI DD ET AL. 2008. Advances in hatchery and grow-out technology of cobia Rachycentron canadum (Linnaeus). Aquac Res 39: 701-711.

BROWN CL AND BERN HA. 1989. Thyroid hormones in early development, with special reference to teleost fish. In: Schreibman MP and Scanes CG (Eds), Hormones in development, maturation and senescence of neuroendocrine systems. A comparative approach. New York: Academic Press, New York, USA, p. 289-306.

Decuypere E, VAN Asa P, VAN Der GeYten SY AND DARRAS VM. 2005. Thyroid hormone availability and activity in avian species: A review. Domest Anim Endocrin 29: 63-77.

Delgado JBO, Ruane NM, Pousão-Ferreira P, Dinis MT AND SARASQUETE C. 2006. Thyroid gland development in Senegalese sole (Solea senegalensis Kaup 1858) during early life stages: A histochemical and immunohistochemical approach. Aquaculture 206: 346-356.

DomínGUEZ RP AND HoLT GJ. 2006. Interrenal and thyroid development in red drum (Sciaenops ocellatus): Effects of nursery environment on larval growth and cortisol concentration during settlement. Gen Comp Endocr 14: 108-118.

EALES JG AND BROWN SB. 1993. Measurement and regulation of thyroidal status in teleost fish. Rev Fish Biol Fisher 3: 299-347.

EINARSDÓTTIR IE, NADIA SD, Power M AND HeIdDIS SBTB. 2006. Thyroid and pituitary gland development from hatching through metamorphosis of a teleost flatfish, the Atlantic halibut. Anat Embryol 211: 47-60.
FAULK CK, BENNINGHOFF AD AND Holt GJ. 2007. Ontogeny of the gastrointestinal tract and selected digestive enzymes in cobia Rachycentron canadum (L.) J Fish Biol 70: 567-583.

FAULK CK AND Holt GJ. 2005. Advances in rearing cobia Rachycentron canadum larvae in recirculating aquaculture systems: live prey enrichment and green water culture. Aquaculture 249: 231-243.

FRASER TWK AND DAVIES SJ. 2009. Nutritional requirements of cobia, Rachycentron canadum (Linnaeus): A review. Aquac Res 40: 1219-1234.

GORBMAN A, DickHOFF WW, VignA SR, ClARK NB AND RALPH CL. 1983. The thyroid gland. In: Comparative Endocrinology. J Wiley \& Sons, New York, USA, p. 185-276.

INUI Y AND MIWA S. 1985. Thyroid hormone induces metamorphosis of flounder larvae. Gen Comp Endocrinol 60: 450-454.

KLAREN PHM, WUNDERINK YS, YÚFERA M, MANCERA JM AND FLIK G. 2008. The thyroid gland and thyroid hormones in Senegalese sole (Solea senegalensis) during early development and metamorphosis. Gen Comp Endocr 155: 686-694.

LAM TJ. 1980. Thyroxine enhances larval development and survival in Sarotherodon (Tilapia) mossambica Ruppel. Aquaculture 21: 287-291.

LEAÑo EM, GuO JJ, Changand SL AND LiaO IC. 2003. Levamisole enhances non-specific immune response of cobia, Rachycentron canadum, fingerlings. J Fisher Soc Taiwan 30: 321-330.

Liao IC, Huang TS, Tsai WS, Hsueh CM, Chang SL and LEAÑO EM. 2004. Cobia culture in Taiwan: current status and problems. Aquaculture 237: 155-165.

LIN JHY, CHEN TY, CHEN MS, CHEN HE, CHOU RL, CHEN TI, SU MS AND YANG HL. 2006. Vaccination with three inactivated pathogens of cobia (Rachycentron canadum) stimulates protective immunity. Aquaculture 255: 125-132.

PiÑUela C, RENDÓN C, GonZÁleZ-CANAles ML AND SARASQUETE C. 2004. Development of the Senegal sole, Solea senegalensis forebrain. Eur J Histochem 48: 377-384.

POWER DM. 2001. Thyroid gland development in a marine teleost, Sparus aurata (Linnaeus, Sparidae). Bol Mus Mun Funchal 6: 433-443.

Resley MJ, WebB KA AND Holt GJ. 2006. Growth and survival of juvenile cobia, Rachycentron canadum, at different salinities in a recirculating aquaculture system. Aquaculture 253: 398-407.

Rodrigues RV, Schwarz MH, Delbos BC, CARVAlHo EL, ROMANO LA AND SAMPAIO LA. 2011. Acute exposure of juvenile cobia Rachycentron canadum to nitrate induces gill, esophageal and brain damage. Aquaculture 323: 223-226.

Rodrigues RV, SCHWARZ MH, DELBOS BC AND SAMPAIO LA 2007. Acute toxicity and sub lethal effects of ammonia and nitrite for juvenile cobia Rachycentron canadum. Aquaculture 271: 553-557.

SAlgAdo GA, VÁsQuez B AND Sol M. 2011. Estereología de La Glándula Tiroides Humana. Int J Morphol 29: 562-567. 
SAlze G, Ewen M And Steven RC. 2011. Pepsin ontogeny and stomach development in larval cobia. Aquaculture 324: 315-318.

SAMPAIO LA, MOREIRA CB, MirandA-FILHO KC AND RoMBENSO AN. 2011. Culture of cobia Rachycentron canadum (L) in near-shore cages off the Brazilian coast. Aquac Res 42: 832-834.

SANTAMaría CA, Marín De Mateo M, TraVeset R, SALA R, Grau A, PAstor E, SARAsquete C AND Crespo S. 2004. Larval organogenesis in common dentex Dentex dentex L. (Sparidae): Histological and Histochemical Aspects. Aquaculture 237: 207-228.

SHAFFER RV AND NAKAMURA EL. 1989. Synopsis of biological data on the Cobia Rachycentron canadum (Pisces: Rachycentridae). NOAA Technical Report NMFS 82. U.S. Department of Commerce, Washington, DC.

SOMMERS SC. 1977. Thyroid gland. In: Anderson WAD and Kissane JM (Eds), Pathology. Saint Louis. CV Mosby Company, Saint Louis, USA, p. 1629-1647.

TAGAWA Mand HiRANO T. 1987. Presence of thyroxine in eggs and changes in its contents during early development of chum salmon, Oncorhynchus keta. Gen Comp Endocrinol 68: 129-135.
TAGAWA M AND HIRANO T. 1990. Changes in tissue and blood concentrations of thyroid hormones in developing chum salmon. Gen Comp Endocrinol 76: 437-443.

TAKASHIMA F AND HiBIYA T. 1995. Endocrine organs. In: Takashima F and Hibiya T (Eds), An atlas of fish histology: Normal and pathological features. Kodansha LTD. Japan, p. 166-168.

Tanaka M, Tanangonan JB, Tagawa M, De Jesus EG, NishidA H, ISAKA M, KimURA R AND Hirano T. 1995. Development of the pituitary, thyroid and interrenal glands and application of endocrinology to the improved rearing of marine fish larvae. Aquaculture 135: 111-126.

URbinati EL, VASQUes LH, SENHORINI JA, SOUZA VL AND GONÇALVES FD. 2008. Larval performance of matrinxã, Brycon amazonicus (Spix \& Agassiz 1829), after maternal triiodothyronine injection or egg immersion. Aquac Res 39: $1355-1359$.

WeIBEL ER 1980. Stereological Methods. Vol. 2: Theoretical Foundations. London, Academic Press, p. 253-257.

YAMANO K. 2005. The role of thyroid hormone in fish development with reference to aquaculture. Jpn Agr Res Q 39: 161-168. 
